\title{
Morphology of seamounts at the Mendeleev Rise, Arctic Ocean
}

\author{
Evgeny Guseva, Pavel Rekant ${ }^{\mathrm{a}}$, Valery Kaminskya, Alexey Krylov ${ }^{\mathrm{a}, \mathrm{b}}$, Andrey Morozovc, Sergey Shokalsky ${ }^{\mathrm{d}}$ \\ \& Sergey Kashubin ${ }^{\mathrm{d}}$ \\ a.S. Gramberg All-Russian Scientific Research Institute for Geology and Mineral Resources of the Ocean, Geological mapping \\ department, St. Petersburg, St Petersburg, Russia; 'bSt Petersburg State University, Institute of Earth Sciences, St Petersburg, Russia; \\ 'Federal Agency on Mineral Resources, Geological Foundations Department, Moscow, Russia; ${ }^{\mathrm{d}}$ A.P. Karpinsky Russian Geological \\ Research Institute, Department of composite geological mapping, St Petersburg, Russia
}

\section{ABSTRACT}

Geological and geophysical studies undertaken during the Russian Arktika-2012 Expedition of 2012 produced evidence of basement outcrops on the steep slopes of the Mendeleev Rise seamounts. Observations of the outcrops from research submarines showed that part of the steep slopes interpreted as basement outcrops based on seismic data were overlain by a light sediment cover. The actual areas of the basement outcrops are therefore much less than indicated by the seismic data alone. The outcrops found are of 5-10 to 100-200 m and are often stretched along some hypsometric level or arranged obliquely, crossing a slope at an angle to the horizon. The rocks are massive and layered, often strongly weathered, cavernous, with visible fissures and extended by dislocations.

\section{KEYWORDS}

Ocean geomorphology; submarine landscapes; slope structures; Arctic Ocean; Mendeleev Ridge

\section{Introduction}

The Mendeleev Rise is an aseismic ridge within the Amerasian Basin in the Arctic Ocean. A recently published geomorphological map of the Arctic region (Harris et al. 2014) shows seamounts in different parts of the Mendeleev Rise. Their morphology is as an ensemble of geological structures: plateaus, terraces and seamounts. Wide flat-topped plateaus, occasionally dissected by fault zones, are widespread in its southern part. These faults are pronounced in seafloor topography as scarps striking north-west. The ' $\mathrm{T}-3$ ' (not formally named), Arlis and Sorgo plateaus, discovered in 1968-1973 by the US drifting scientific station Fletcher's Ice Island, are prominent here (Hall 1979). The names for the remaining seamounts within the Mendeleev Rise were given pursuant to the General Bathymetric Chart of the Oceans Undersea Feature Names Gazetteer (http://www. ngdc.noaa.gov/gazetteer/). Flat tops of some plateaus close to the margin are eroded and their surfaces are covered with subglacial scores and grooves (Niessen et al. 2013). The formation of these structures is likely to be caused by an ice sheet (Polyak et al. 2001; Niessen et al. 2013; Dove et al. 2014), large drifting icebergs and mega-icebergs (Kristoffersen et al. 2004). Near $81^{\circ} \mathrm{N}$, the Mendeleev Rise topography distinctly deepens. Only a few seamounts with a rather large relative height are observed. The orientation of major morphological structures changes from north-westsouth-east to north-east-south-west. Thickness of sediments covering the positive forms of relief is greatly reduced $(<1 \mathrm{~km})$.

A long-held conception was that the Mendeleev Rise was almost completely covered by sediment $0.5-2 \mathrm{~km}$ in thickness (e.g., Backman et al. 2004; Bruvoll et al. 2010), excluding a possibility of finding bedrock outcrops on the seafloor. Seismic surveys indicated that in only a few locations on steep slopes, formed by tectonic dislocations, were basement rocks exposed on the surface of the seabed (Hunkins et al., 1970; Hall 1979).

The first confident indications of basement outcrops on the seafloor were obtained from aboard the US Coast Guard icebreaker Healy in 2005. Two fragments of seismic profiles crossing the steep slopes recorded acoustic basement close to the seafloor surface (Dove et al. 2010). Multibeam bathymetry conducted in 201011 by Russian hydrographers revealed slopes with angles steeper than $30^{\circ}$ within the Mendeleev Rise seamounts, making the existence of basement outcrops likely (Glumov et al. 2012).

The structural features of the Mendeleev Rise seamount slopes and determining the existence or absence of basement outcrops on the seafloor surface are important to constrain the nature and geological evolution of this prominent ridge. Many researchers believe that the rock fragments, namely coarse sand and gravel products recovered from the crest of the Mendeleev Ridge, are icerafted debris originating mainly in the Canadian Arctic Archipelago (e.g., Grantz et al. 1998; Grantz et al. 2011; Phillips \& Grantz 2001; Darby \& Zimmerman 2008; 
Stein et al. 2010; Krylov et al. 2014). Kaban'kov et al. 2004, 2008) and Rekant et al. (2013), however, state that most of the samples recovered by Russian expeditions are in situ rocks.

Local origin is generally accepted for rock fragments sampled from the other ridges in the Arctic Basin. These are characterized by more contrasting topography in comparison with the Mendeleev Rise, with its outcrops of acoustic basement on the seafloor surface as the seismic data indicate. For example, a basalt fragment cored with a gravity corer at a steep slope of Alpha Ridge is considered to represent the basement (Jokat 2003). Most of the rock fragments cored from the slopes of the Northwind Ridge are considered local as well, representing the ridge basement (Grantz et al. 1998).

\section{Methods}

During the Arktika-2012 cruise, geophysical studies were carried out aboard the icebreaker Dikson and covered both the Mendeleev Rise and adjacent structures: Podvodnikov Basin, Mendeleev Basin, the Chukchi Plateau and a continental slope (Fig. 1). Geological studies were focused on the Mendeleev Rise at 10 sites (KS 0-9) and surveyed from research submarines and the icebreaker Kapitan Dranitsyn. The set of studies included multibeam echo sounding, seismic reflection profiling from icebreaker, sub-bottom chirp sonar profiling and video survey for outcrops on the seafloor from a distance of $10-20 \mathrm{~m}$ from the submarine.

Sampling was undertaken from the Kapitan Dranitsyn and a research submarine. The preliminary locations of the sampling sites were selected using multi-channel seismic data to determine sites where

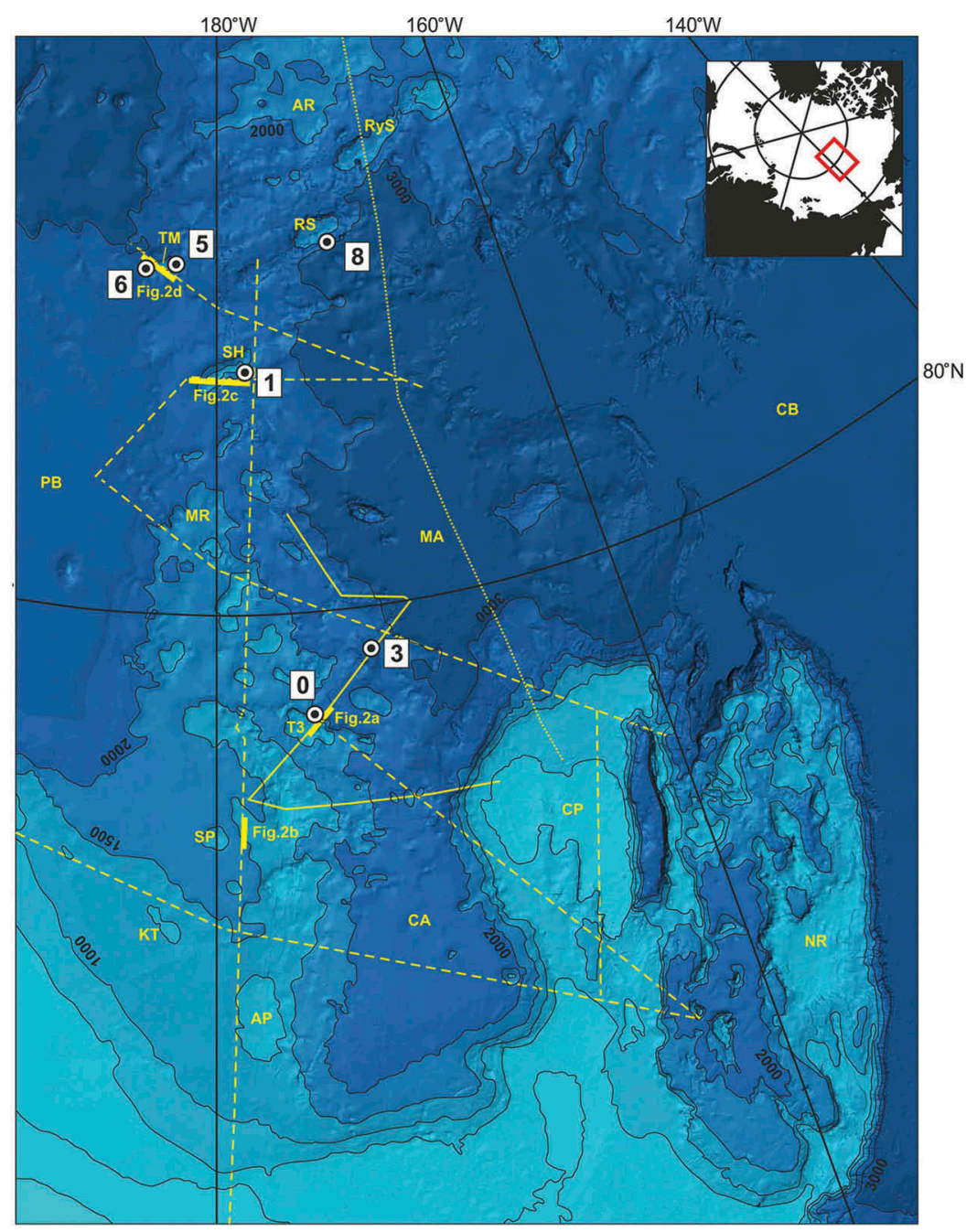

Figure 1. Overview of the Mendeleev Ridge and adjacent areas. Bathymetry from the International Bathymetric Chart of the Arctic Ocean (Jakobsson et al. 2012). Yellow lines mark the seismic reflection profiles of the Healy 2005 survey cruise (Bruvoll et al. 2010; Bruvoll et al. 2012). Yellow dotted lines mark the seismic reflection profiles of the 2011 Canadian High Arctic Seismic Expedition surveys (Mosher 2012; Bruvoll et al. 2012.). Yellow dashed lines mark the seismic reflection profiles of the Arktika-2012 Expedition surveys. Boldface yellow lines indicate the location of figures. Dots and numbers mark key sites (KS) identified during submarine and icebreaker surveys. Abbreviations: AP - Arlis Plateau; AR - Alpha Ridge; CA - Chukchi Abyssal Plain; CB - Canada Basin; CP - Chukchi Plateau; KT - Kucherov Terrace; MA Mendeleev Abyssal Plain; MR - Mendeleev Rise; NR- Northwind Ridge; PB - Podvodnikov Basin; RS - Rogotsky Seamount; RyS - Ryabov Seamounts; SH - Shamshur Seamount; SP - Sargo Plateau; T3 - 'T-3' plateau; TS - Trukshin Seamount; WA - Wrangel Abyssal Plain. 
acoustic basement outcroppings occurred at sharp seabed escarpments. Then those sites were visually examined and documented by (by EAG) from the research submarine to locate more precisely the outcropped acoustic basement (Gusev et al. 2013; Gusev et al. 2014). The drilling sites were chosen at relatively flat seafloor (less than $20^{\circ} \mathrm{dip}$ ), without any sedimentary cover, with conditions allowing for drilling of the rock up to a depth $2 \mathrm{~m}$ below sea floor from the Kapitan Dranitsyn (Shkatov \& Ivanov 2013). Sampling from the submarine employed a manipulation arm; seven samples of boulders, up to $0.5 \mathrm{~m}$ in size and weighing $5-30 \mathrm{~kg}$, were taken at sites close to the outcrops. Details on the sampling from the research submarine with its special devices have been presented by Aibulatov et al. (2005).

\section{Results}

\section{Seismic evidence for basement outcrops}

Our new seismic data confirm the existence of acoustic basement outcrops along steep scarps.
They are mainly located in the northern part of the Mendeleev Rise, close to the junction with the Alpha Ridge $\left(82-83^{\circ} \mathrm{N}\right)$ and in the southern part of Mendeleev Ridge $\left(78-79^{\circ} \mathrm{N}\right)$. In the first area, steep slopes of the Ryabov Seamount (Fig. 1) lack sedimentary cover. Basement outcrops exposed on the seafloor were detected on profile 4 (Mosher 2012). According to our new seismic data the areal extent of the basement outcrops is about $300 \mathrm{~m}$ within $\mathrm{KS} 0$ ('T-3' plateau), approximately $700 \mathrm{~m}$ in the area of an unnamed fault zone (Fig. 2b), $400 \mathrm{~m}$ on the slope of the Shamshur Seamount (KS 1) and about $800-900 \mathrm{~m}$ on the slopes of the Trukshin Seamount (KS 5 and 6) (Fig. 2d).

Multi-channel seismic data of the studied KS suggest that some slopes have a very thin sediment cover. Across the western slope of the Trukshin Seamount (KS 6), a sub-bottom chirp sonar profiler investigated the shallow structure of the crests and canyons, breaking the slope. The data (Fig. 3) show that seamount slopes are covered with a layer of loose sediments with thicknesses varying from 1 to $5 \mathrm{~m}$. (a)

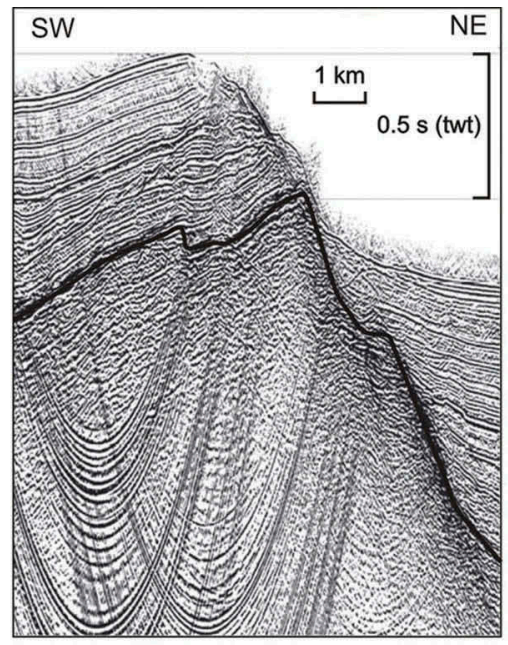

(c) W

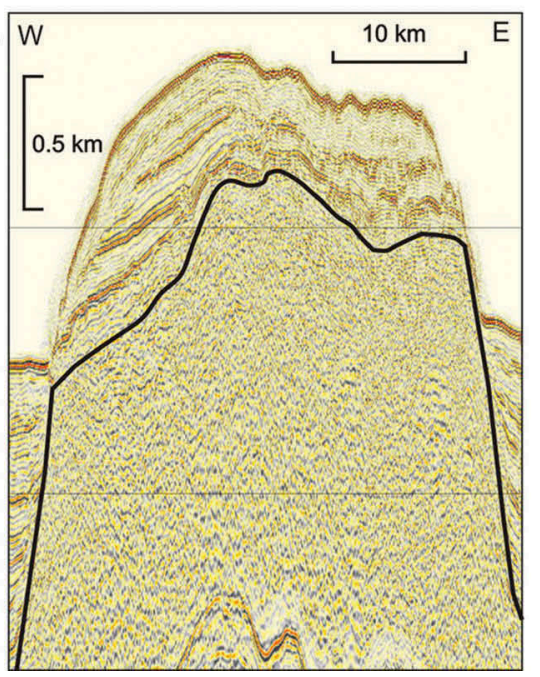

(b)

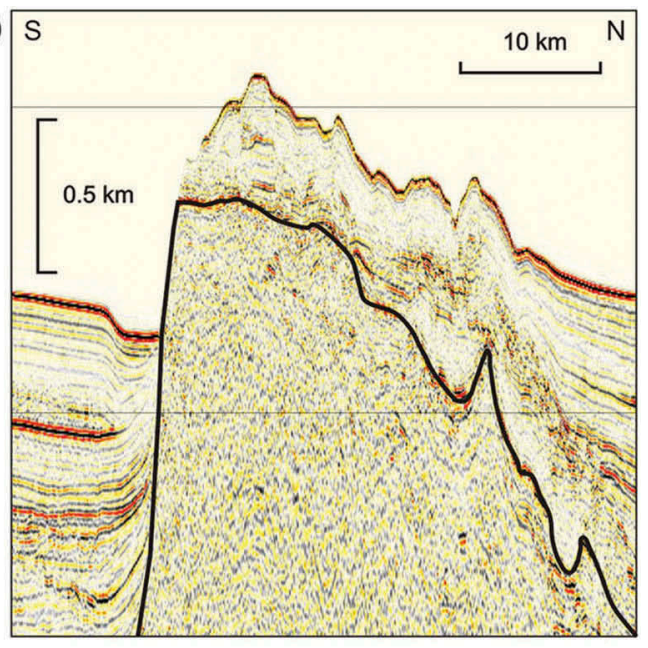

(d)

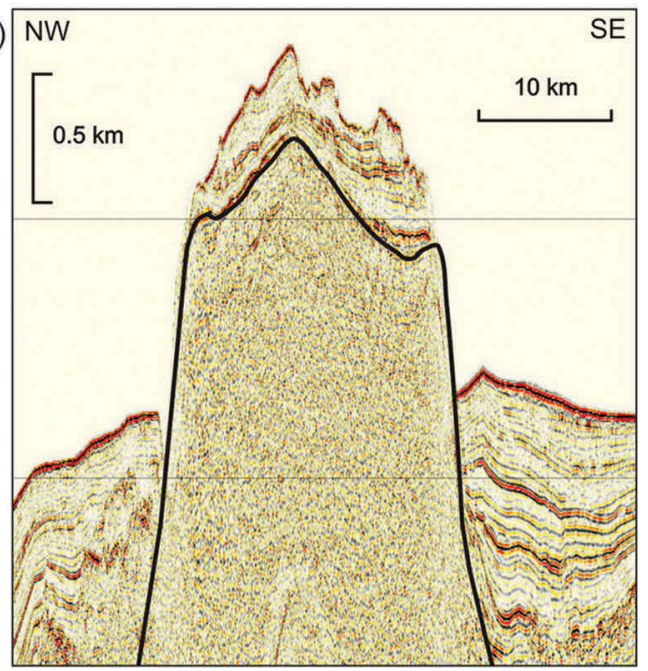

Figure 2. Parts of cross-feature seismic profiles where basement outcrops are likely. See locations in Fig. 1. (a) The seismic reflection profile $\mathrm{H} 0522$ was acquired perpendicular to the 'T-3' plateau slope (Dove et al. 2010). (b-d) Sections from the Arktika2012 Expedition seismic profiles: (b) unnamed feature at 78 N, (c) Shamshur Seamount, (d) Trukshin Seamount. See locations in Fig. 1. Boldface lines mark the acoustic basement. 


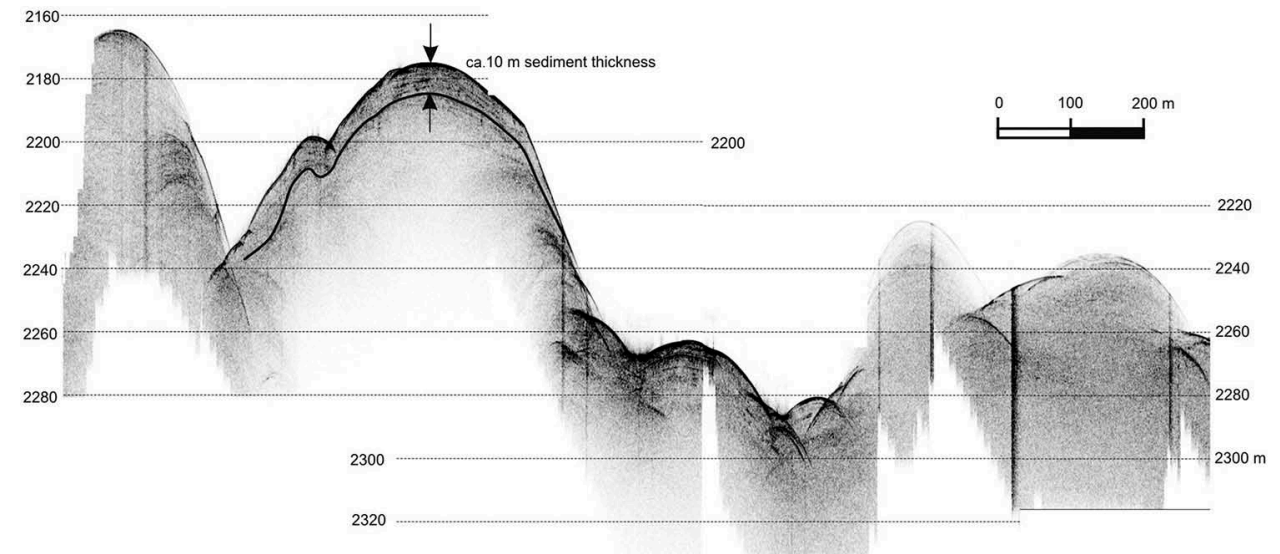

Figure 3. Sub-bottom chirp sonar profile along the slope of Trukshin Seamount (KS 6). Ridges and canyons are covered by a thin layer of sediments (1-10 m).

\section{Rock samples obtained from seamount slopes}

We tried to retrieve basement rock samples from 10 key sites. This article presents data for the six sites for which we obtained reliable data, allowing us to determine whether basement outcrops were present or absent.

KS 0 is located on the 'T-3' plateau slope (Hall 1979) at a water depth of $1100 \mathrm{~m}$. The slope have north-eastern exposure in a north-easterly direction and has gradients of $30-45^{\circ}$. The slope is complicated by submarine canyons with dividing ridges and crests. According to seismo-acoustic studies obtained by a profiler, large areas of the canyons' sides are not covered with sediments. In the lower part of the slope a basement outcrop was discovered. This outcrop is characterized by an irregular surface separated into large blocks by deep, gaping fissures. Some of these fissures probably represent disjunctive dislocations, extending for tens of metres (Fig. 4). Shallow borehole KD12-00-33b $\left(79^{\circ} 01.45^{\prime} \mathrm{N}, 174^{\circ} 55.1^{\prime} \mathrm{W}\right.$; water (a)

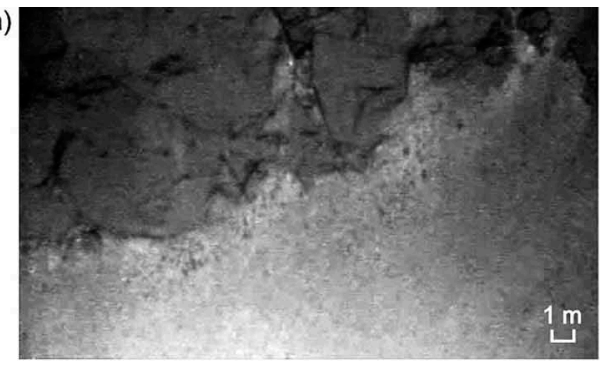

(c)

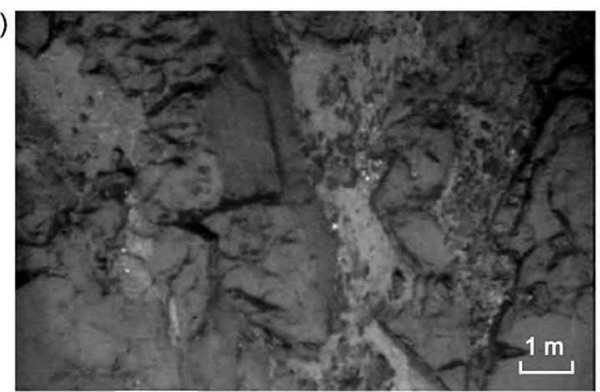

(e)

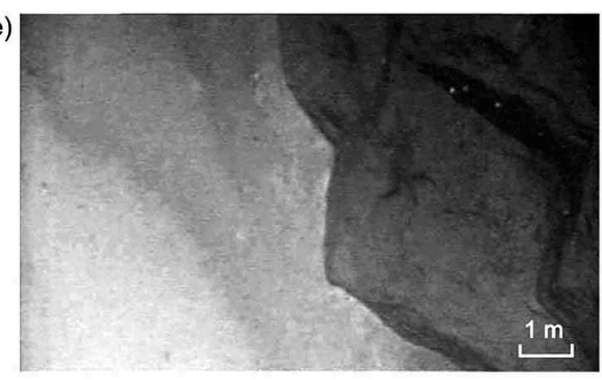

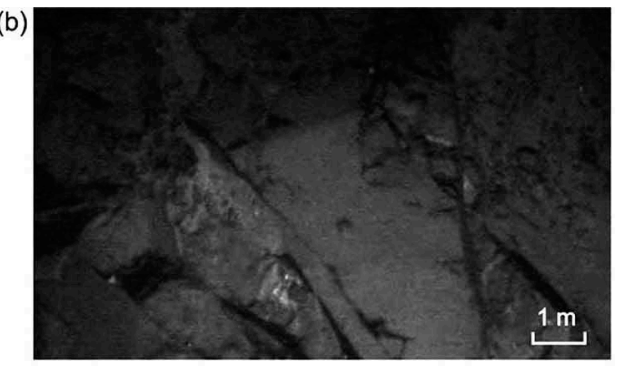
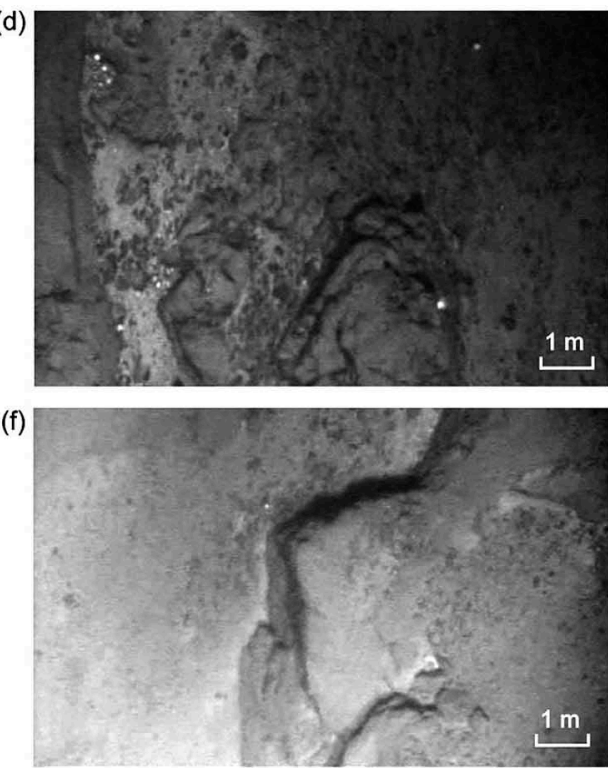

Figure 4. Basement bedrock outcrops on KS 0, made from deepwater submarine. (a) The foot of slope; rocks are dark and sediments are light. (b) Fractured bedrock surface. (c, d) Bedrock outcrop and rock fragments. (e, f) Bedrock outcrop with angular outlines. 
depth $2260 \mathrm{~m}$ ) was drilled on the bench of rock surface, at the piedmont of 'T-3' plateau (KS 0) (Morozov et al. 2013; Shkatov \& Ivanov 2013). The retrieved rocks are almond-shaped trachy basalts of Permian age (ca. $260 \mathrm{My}(\mathrm{a})$ ) based on zircon dating (Morozov et al. 2013). However, the ${ }^{40} \mathrm{Ar} /{ }^{39} \mathrm{Ar}$ dating of the core samples provides a different age of 435-470 My(a) (Vernikovsky et al. 2014).

KS 1 is located in the northern part of the Mendeleev Rise $\left(82^{\circ} \mathrm{N}\right)$, within the southern slope of the Shamshur Seamount at $1363 \mathrm{~m}$ water depth. Here, we studied its south-eastern slope, with gradients up to $25-46^{\circ}$. The steepest gradients are found in the lower part of the slope, as well as in canyons' sides and on the crests' walls. As shown by sub-bottom chirp sonar data and confirmed by visual observations from a research submarine, sedimentary thickness on the steep areas is highly reduced until it is pinching out. At the lower part of the seamount slopes, exposed bedrock with an uneven and hummocky surface was discovered. Eluvium and slumped sediments were also observed.

At site KS 3 no basement outcrops were recovered (Fig. 5). The slopes were covered with a thick layer of sediments. A video survey at the piedmont of the slope and on the flat top of the mount showed that rock fragments are extremely rare, regularly distributed on the seafloor and probably represent ice-rafted material (Fig. 5d). At this location numerous ferromanganese crust-nodule formations and proper crusts, including large samples with the size of fragments up to $50 \mathrm{~cm}$, were dredged from the slope.

On eastern slopes of the Trukshin Seamount (KS 5) seafloor gradients reach $30-40^{\circ}$. The eastern slopes of the crest show a stepped structure controlled by faults with vertical amplitudes of 25-30 m. As shown by seismoacoustic data, sediment thickness on the slopes does not exceed $30 \mathrm{~m}$. On the steep sites the sediments reduce down to 1-2 $\mathrm{m}$ or are absent. At the piedmont, angular rock fragments of different sizes up to $0.5-0.7 \mathrm{~m}$ are frequent. The fragments are grouped into small accumulations that may indicate their simultaneous down-slope transport and subsequent deposition at the piedmont. In the lower part of the slope, on a small ridge descending from the top, thin (5-10 m each) basement outcrops were discovered by observations from a research submarine at a depth of about $2500 \mathrm{~m}$. At shallower depths of the slope $(2350 \mathrm{~m})$, a pronounced scarp was observed. The outcropping rock has an uneven surface and is broken by fissures.

KS 6 is located at the north-western slope of the Trukshin Seamount. Here, the slope has seafloor gradients reaching $35-50^{\circ}$. The steepest areas are confined at the sides of a large submarine canyon and conjugated ridge (Fig. 6). According to seismo-acoustic data, sediments are about $20 \mathrm{~m}$ thick at the bottom of the canyon, while on the steep slopes of its sides the thickness reduces to $1-2 \mathrm{~m}$. Please note that a few sites along the slopes show no evidences for sediments at all.

The seamount foot is covered with clayey mud, and rock fragments are rare in the Podvodnikov Basin at some distance from the seamount piedmont. Closer to the slope, the number of rock fragments increases. They look fresher and are irregularly shaped. Near the mouth of the canyon a pile of the disintegrated rocks up to $10-15 \mathrm{~m}$ in size was found. The rock surface is uneven, porous and cavernous, indicating considerable weathering. Most likely the blocks have been removed from the slope towards the piedmont by a mass waste. More (a)

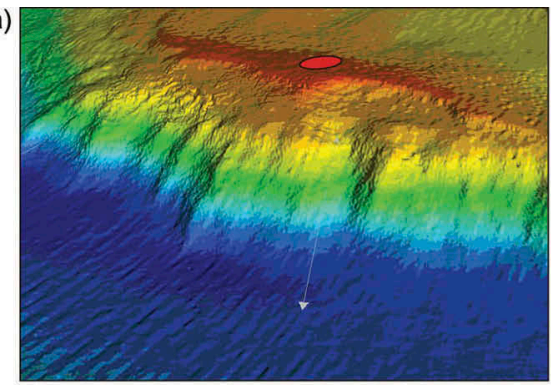

(c)

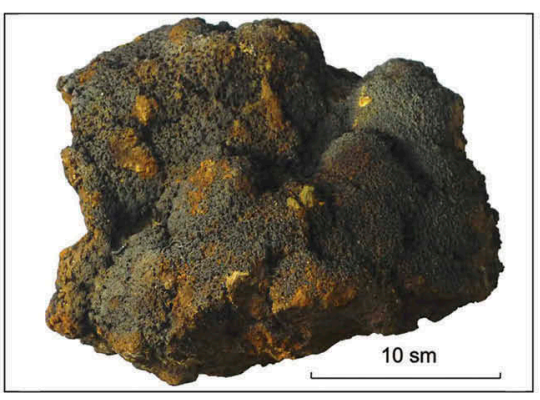

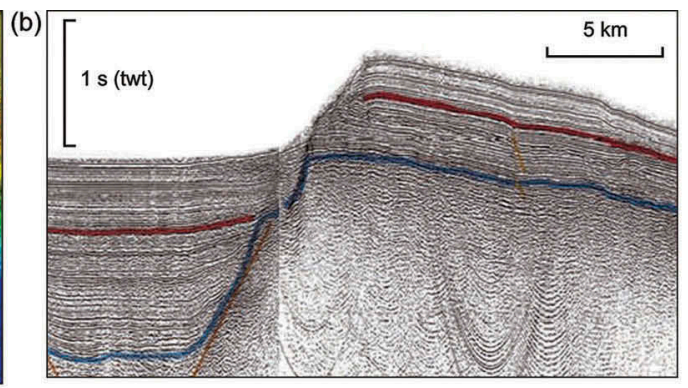

(d)

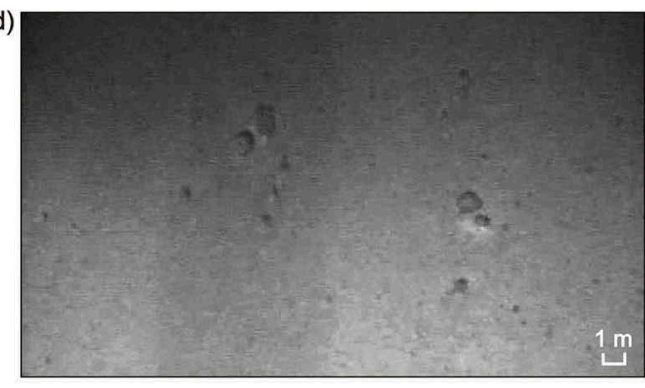

Figure 5. Mendeleev Rise structure at KS 3. (a) Multibeam bathymetry, the red oval shows the area where a near-bottom survey with video recording were conducted from a research submarine. (b) Seismic reflection profiles HLY0522 and HLY0523 (Dove et al. 2010 ); the slope of the seamount is covered by a thick sediment layer. (c) Fe-Mn concretion dredged from the slope. (d) Ocean floor photo with large pieces of ice-rafted debris on the top of the seamount; location shown in (a). 

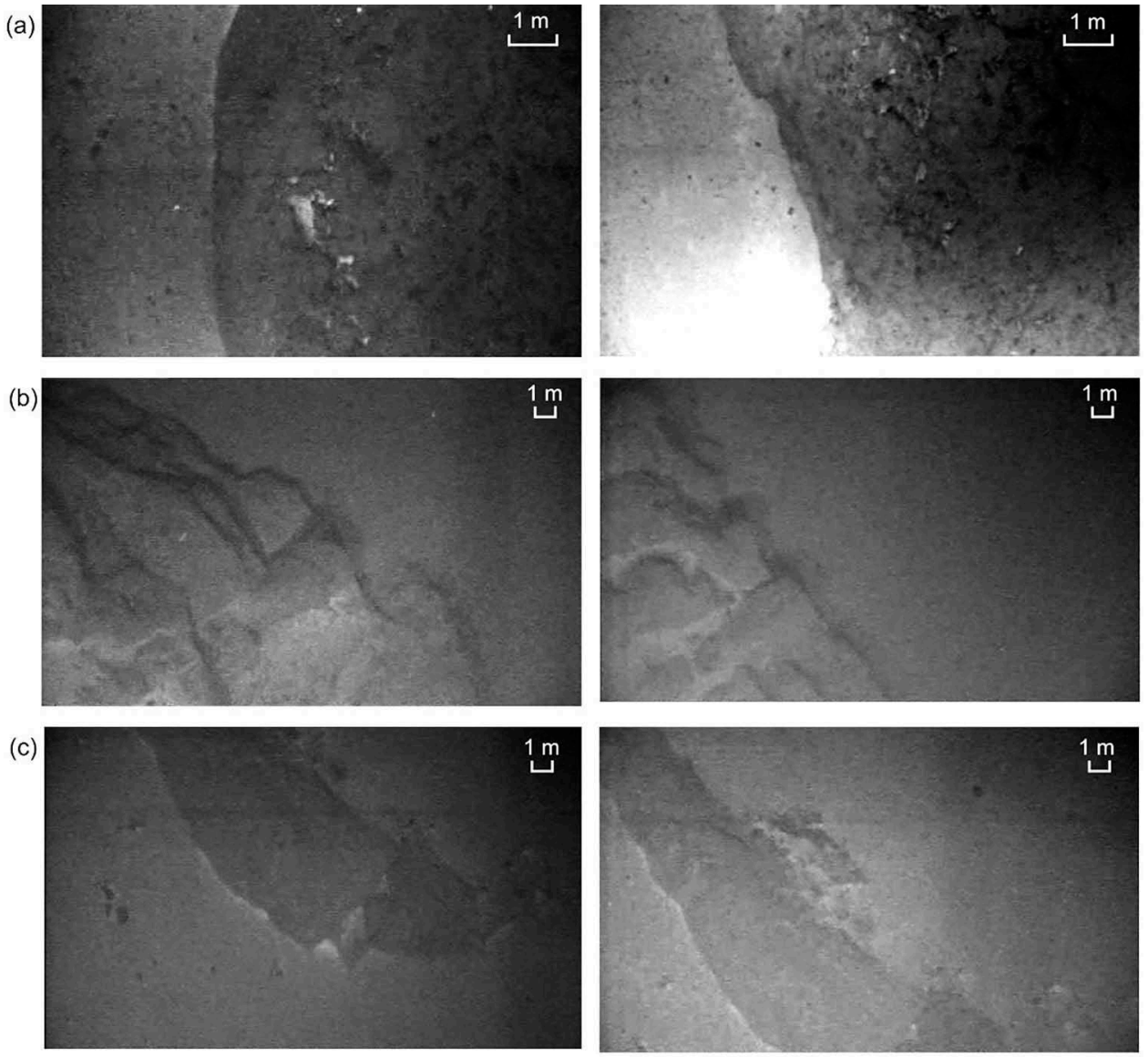

Figure 6. Photos of basement bedrock outcrops at KS 6 taken from a research submarine. (a) 10-m distance from the object. (b, c) 20-m distance from the object. Photos on the right-hand side were taken from the port side; photos on the left were taken from starboard. (a) Weathered surface of the bedrock outcrop near the foot of the seamount slope. (b) Fractured bedrock and (c) elongated bedrock outcrop in the central part of the slope.

upwards a single, small basement outcrop was discovered. The surface of basement rocks is uneven (Fig. 6a) and the rocks are broken with fissures (Fig. 6b, c). A pronounced scarp was discovered in the relief of the basement outcrop. At KS 6, one shallow borehole (KD12-06-21b) was drilled on a small terrace $\left(83^{\circ} 05.36^{\prime}\right.$ $\mathrm{N}, 175^{\circ} 44.42^{\prime} \mathrm{E}$, sea depth of $2600 \mathrm{~m}$ ) (Morozov et al. 2013; Shkatov \& Ivanov 2013). A volcanic trachy basalt breccia penetrated by the borehole is $127.5 \pm 2.7 \mathrm{My}(\mathrm{a})$ old as determined by zircon dating (Morozov et al. 2013). Again, a ${ }^{40} \mathrm{Ar} /{ }^{39} \mathrm{Ar}$ dated sample from this borehole shows a very different age of $237 \pm 2 \mathrm{My}(\mathrm{a})$ (Vernikovsky et al. 2014).

A detailed bathymetric map compiled on a base of multibeam echo sounding profile (Fig. 7b, c) clearly shows the distinct cirque-shaped lows transforming into valleys with trough-shaped transverse sections. These valleys are separated in all directions from the mount top towards the edges of the flat-topped surface. The valleys are about 3-4 $\mathrm{km}$ wide. Relative depth of the valleys is no more than $50-80 \mathrm{~m}$. Within the multibeam profile, only the upper reaches of most of the trough valleys begin with a sharply cirque-shaped steep slopes. Only one of these sub-latitudinal oriented valleys is visible from the upper reaches of its release on the edge of the steep slope of the mount (Fig. 7c). In the place where the valley exits to the steep slope of the Trukshin Seamount, on the northern slope, a profiler recorded a crest similar to a lateral moraine of the glacier. However, the borehole (KD-12-05-23c; 830․ ${ }^{\circ} \mathrm{N}, 177^{\circ} 12.6^{\prime} \mathrm{E}$; sea depth $1890 \mathrm{~m}$ ) cored within the valley penetrated about $4 \mathrm{~m}$ of sediments exclusively composed of pelagic silty clay. No traces of moraine diamicton and erratic glacial material were detected in the cored material. The sediments show soft-plastic consistency typical of oceanic sediments. No ranges were recorded near the southern slope of the described valley mouth. The seismic profile ARC1205 (Fig. 2d) running across the Trukshin Seamount in a sub-latitudinal direction distinctly shows an uneven surface of the mount top. Apparently, the prominent topographic lows in the profile correspond to trough-shaped valleys.

On the southern slope of the Rogotsky Seamount (KS 8 ) seafloor gradients reach $30-35^{\circ}$. The steepest scarps are observed in the upper part of the slope profile; the slope becomes more gentle towards the piedmont. The relative depth of the canyons along the slope is up to $80 \mathrm{~m}$. Near the mouth of one of the canyons, large-sized rock blocks (5-25 m) were found. The rocks composing the blocks have uneven surfaces, smoothed edges and are broken by 
(a)

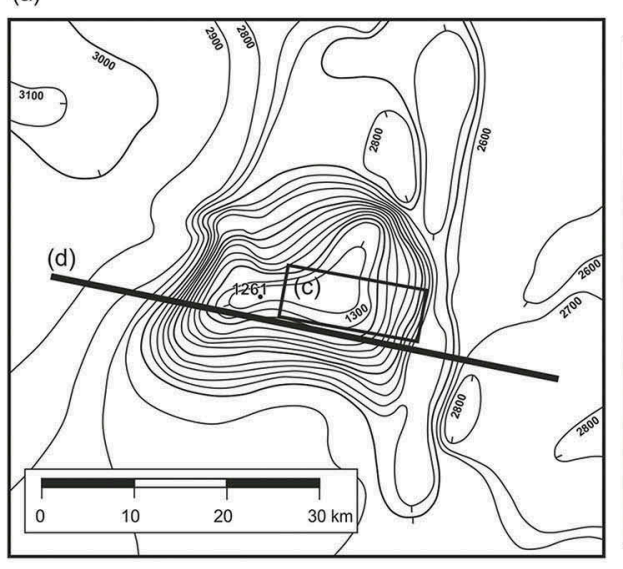

(b)

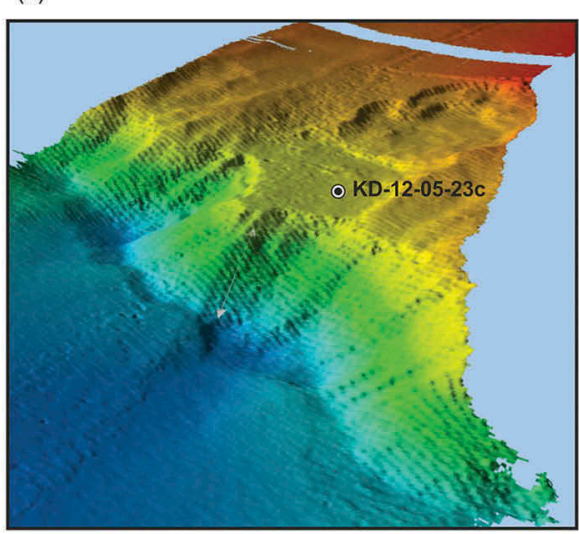

(c)
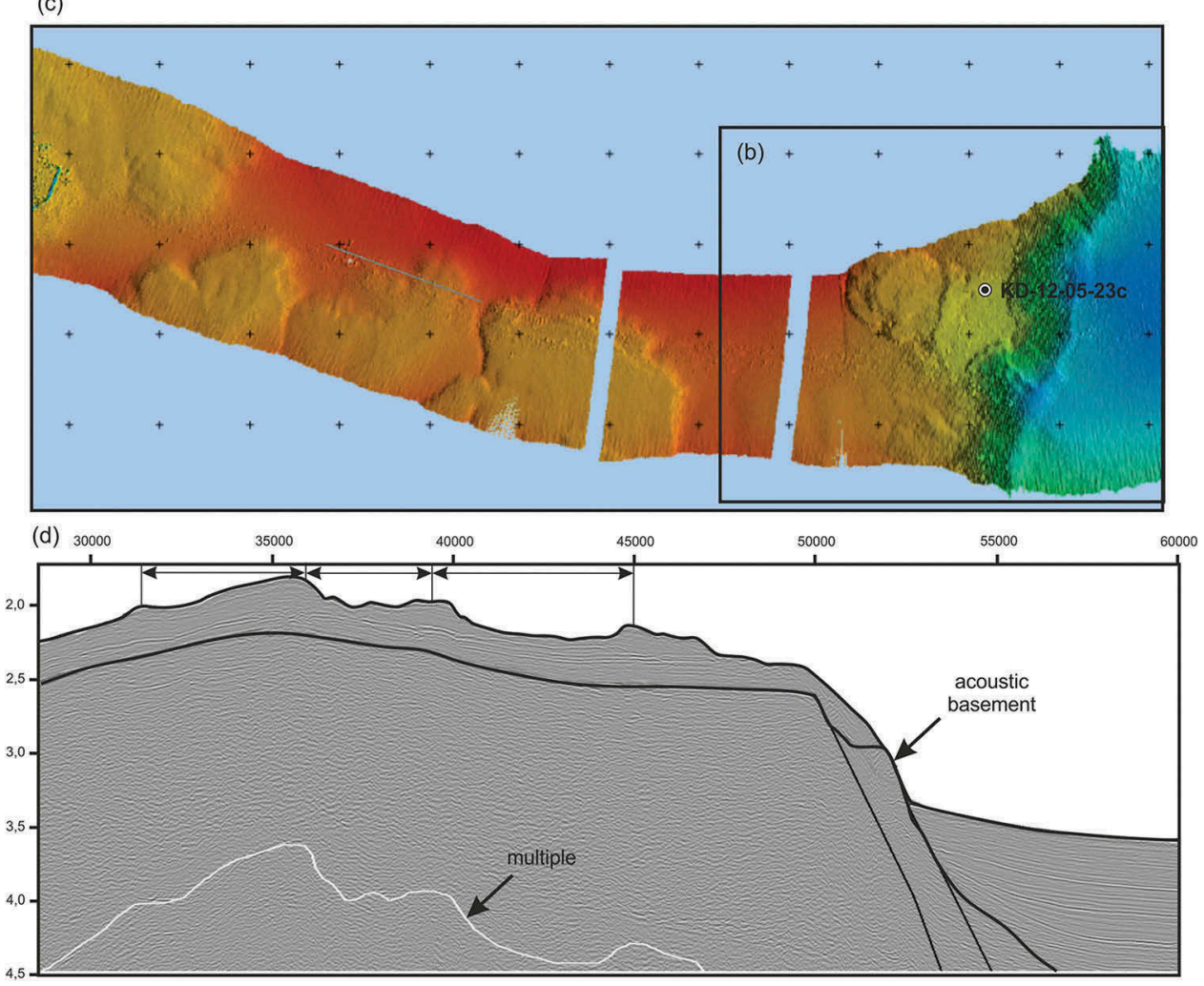

Figure 7. Schematic showing the source of rock fragments sampled from the seafloor of Mendeleev Rise. (a) Gentle slopes, with the basement covered by sediments. Rare ice-rafted debris (IRD) on the flat top of a seamount and on abyssal plains versus concentrated IRD on the foot of the slope. (b) Steep slopes with basement outcrops on the slope. Concentrations of in situ material and IRD should be found on the foot of slope.

shallow fissures. These rock blocks probably originated from the upper steep part of the slope of the Rogotsky Seamount. The dredged samples from slopes consist of limestones, dolomites, sandstones, siltstones, mudstones, basalts and metamorphic schists.

\section{Discussion and conclusion}

\section{Origin of rock fragments on the Mendeleev Rise mount slopes}

New geological and geophysical data obtained during the Arktika-2012 cruise indicate the likely presence of basement outcrops along the Mendeleev Rise. These outcrops vary in sizes and have significantly different surfaces. Direct observations of these basement outcrops combined with data obtained from coring are still insufficient to determine with certainty the origin of the rocks sampled from the seamount slopes. The basement outcrops that were immediately observed from the submarine ship within the key sites are: KS 0 ('T-3' plateau), KS 1 (Shamshur Seamount), KS 5 and 6 (Trukshin Seamount). In contrast to the drilling samples, which mainly consist of magmatic material, the dredged material comprises a wide range of sedimentary, metamorphic and magmatic rocks. It should be noted that in both onshore and offshore mountain slopes, magmatic rocks are usually 

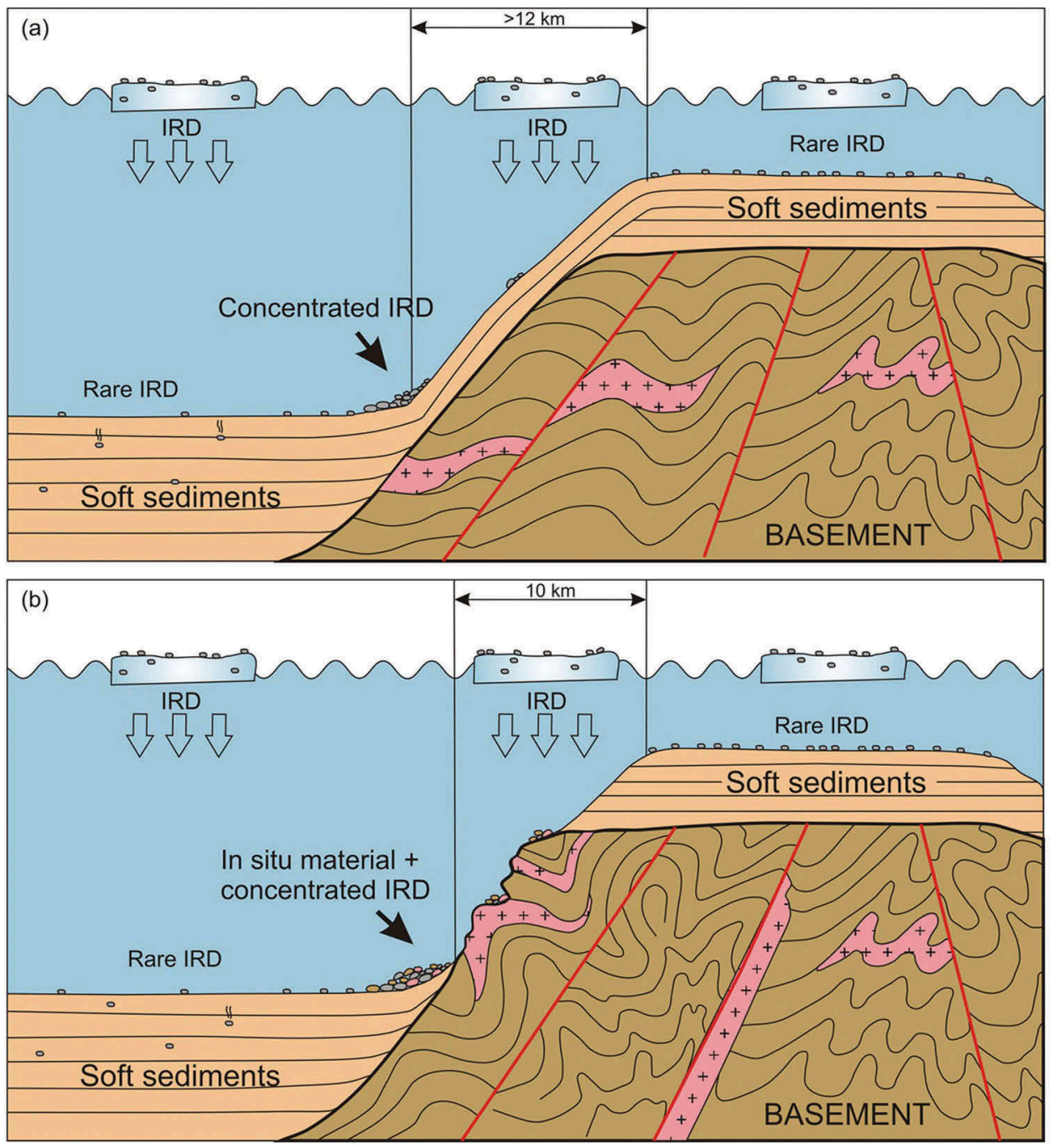

Figure 8. Trukshin Seamount structures. (a) Bathymetric scheme. (b) Multibeam bathymetric perspective image of the eastern slope of the seamount. (c) Multibeam bathymetric map of the seamount's top and eastern slope. (d) The Arktika-2012 Expedition seismic profile fragment.

clearly exposed since they resist weathering. Sedimentary rocks, easily eroded, are usually covered with slope material of various thickness. So, magmatic formations penetrated by only two boreholes do not prove an exclusively magmatic genesis for the basement of the Mendeleev Rise as seismic evidence indicated (Bruvoll et al. 2012).

In the southern part of the Mendeleev Rise, rock fragments of different morphologies were detected on a flat top of the seamount (KS 3), overlain by a thick bed of layered sediments. They are interpreted as erratic products and indicate the presence of glacigenic material in bottom sediments. Near the foot of the seamount, which is covered with a relatively thick layer of sediments, rock fragments supplied by sea ice and icebergs are concentrated (Fig. 8a).

Compared to the gentle slopes and flat abyssal planes, there are significantly more rock fragments near the piedmonts of steep slopes and directly at the bases of the basement outcrops and these rocks are also larger in size (Fig. 8b). Large blocks with sharp edges, fresh spalls and distinct uneven faces are frequent. We think that the prominent basement outcrops located in the vicinity are the source of these rock fragments. However, icerafted material makes a definite contribution to the accumulation of large-sized material near the seamount foot. Also, it should be noted that the number of large rock fragments is greater along the topographic highs and is less in the basins. This is quite possibly due to higher sedimentation rates in the basins that dilute the amount of icerafted coarse material. There may also be an extra supply of coarse material to ridges from the nearby outcrops.

\section{Pseudoglacial structures on the seamount slopes}

Structures visually similar to glacial cirques, valleys and marginal landforms with undulating topography typical for terminal and lateral moraines were recorded in the northern part of the Mendeleev Rise at the top of the 
Trukshin Seamount. The mount top represents a flat surface with insignificant centre-to-edges gradients. The plateau-shaped top is surrounded by steep slopes (gradients $20-40^{\circ}$, occasionally up to $78^{\circ}$ ). The shallowest part of the seamount $(1261 \mathrm{~m})$ is located in its western part. The bathymetric map of the mount (Fig. 7a; BKTAB 2002) does not fully display the geomorphological features of this structure. In fact, the plateau-shaped apical surface is quite indistinctly expressed in the map.

The terraces discovered at the rims of the flattopped Shamshur, Rogotsky seamounts and 'T-3' plateau spurs are at a similar depth to the trough valleys on the Trukshin Seamount.

We assume a landslide genesis for the cirque-shaped lows, trough-shaped valleys, sloping terraces and seafloor irregularities. Their sliding on the gentle slopes towards the margins of plateau-shaped top surfaces further continued in the form of turbidity flows. The latter delivered the material down the steep slopes towards the piedmont and evenly distributed it in the form of weakly expressed in the relief cones.

The past seismic activity in the area is confirmed by numerous multidirectional dislocations, recorded by seismic profiles, which break the basement and the entire sedimentary cover of the Mendeleev Rise up to the base of Pliocene-Quaternary sequence (Bruvoll et al. 2010; Hegewald \& Jokat 2013; Smirnov 2013). However, small scale slides can also happen without seismicity. The same structures were found in the southern part of Lomonosov Ridge (see slide scars on fig. 3 in Stein et al. 2016).

\section{Acknowledgements}

The authors express their appreciation to the teams of the Dikson and Kapitan Dranitsyn icebreakers and the research submarines under the Ministry of Defense of the Russian Federation for geological and geophysical investigations, carried out during the Arktika-2012 research cruise. We gratefully acknowledge the constructive review comments made by $\mathrm{W}$. Jokat and an anonymous reviewer.

\section{Disclosure statement}

No potential conflict of interest was reported by the authors.

\section{References}

Aibulatov N.A., Korshunov V.V. \& Egorov A.V. 2005. Selected results of the oceanological studies in the southern part of the Barents Sea from a research submarine. Oceanology 45, 130-139.

Backman J., Jakobsson M., Lovlie R., Polyak L. \& Febo L.A. 2004. Is the central Arctic Ocean a sediment starved basin? Quaternary Science Reviews 23, 1435-1454.

BKTAB 2002. Batimetricheskaya Karta Tsentral'nogo Arkticheskogo Basseina. Masshtab 2,500,000 vdol' 75 paralleli; Stereografičeskaya proekcija. (z 180 - w $180^{\circ} / \mathrm{s} 90^{\circ}-\mathrm{s}$
65\%). (Bathymetry Mmap of the central Arctic Basin. Scale 1:2,500,000 along 75th parallel; Stereographic projection. [W $\left.180^{\circ}-E \quad 180^{\circ} / N \quad 90^{\circ}-N \quad 65^{\circ}\right]$.) Moscow: Glavnoe Upravlenie Navigatsii i Okeanografii (Main Department of Navigation and Oceanography of Russian Ministry of Defense.

Bruvoll V., Kristoffersen Y., Coakley B.J. \& Hopper J.R. 2010. Hemipelagic deposits on the Mendeleev and northwestern Alpha submarine ridges in the Arctic Ocean: acoustic stratigraphy, depositional environment and an inter-ridge correlation calibrated by the ACEX results. Marine Geophysical Research 31, 149-171.

Bruvoll V., Kristoffersen Y., Coakley B.J., Hopper J.R., Planke S. \& Kandilarov A. 2012. The nature of the acoustic basement on Mendeleev and northwestern Alpha ridges, Arctic Ocean. Tectonophysics 514-517, 123-145.

Darby D.A. \& Zimmerman P. 2008. Ice-rafted detritus events in the Arctic during the last glacial interval, and the timing of the Innuitian and Laurentide ice sheet calving events. Polar Research 27, 114-127.

Dove D., Coakley B., Hopper J. \& Kristoffersen Y. HLY0503 Geophysics Team. 2010. Bathymetry, controlled source seismic and gravity observations of the Mendeleev Ridge; implications for ridge structure, origin, and regional tectonics. Geophysical Journal International 183, 481-502.

Dove D., Polyak L. \& Coakley B. 2014. Widespread, multisource glacial erosion on the Chukchi margin, Arctic Ocean. Quaternary Science Reviews 95, 112-122.

Glumov I.F., Zenkov A.F. \& Zhilin D.M. 2012. A challenge in the Arctic. Bathymetric survey for delineation of the extended continental shelf of the Russian Federation. Hydro International 1, 27-30.

Grantz A., Clark D.L., Phillips R.L. \& Srivastava S.P. 1998. Phanerozoic stratigraphy of Northwind Ridge, magnetic anomalies in the Canada Basin, and the geometry and timing of rifting in the Amerasia Basin, Arctic Ocean. Geological Society of America Bulletin 110, 801-820.

Grantz A., Hart P.E. \& Childers V.A. 2011. Geology and tectonic development of the Amerasia and Canadian Basin, Arctic Ocean. In Spencer A.M. (ed.): Arctic petroleum geology. Pp. 771-800. London: Geological Society.

Gusev E.A., Lukashenko R.V., Popko A.O., Rekant P.V., Mirolyubova E.S. \& Pyatkova M.N. 2014. New data on the structure of slopes of the Mendeleev Ridge seamounts (Arctic Ocean). Doklady Earth Sciences 455, 250-253.

Gusev E.A., Rekant P.V., Vinogradov V.A., Zinchenko A. G. \& Shkarubo S.I. 2013. Regional geological mappingthe basis for study and mastering of mineral resources potential of Arctic. Gorny Zhurnal 11, 10-14.

Hall J.K. 1979. Sediment waves and other evidence of paleo-bottom currents at two locations in the deep Arctic Ocean. Sedimentary Geology 23, 269-299.

Harris P.T., Macmillan-Lawler M., Rupp J. \& Baker E.K. 2014. Geomorphology of the oceans. Marine Geology $352,4-24$.

Hegewald A. \& Jokat W. 2013. Tectonic and sedimentary structures in the northern Chukchi region, Arctic Ocean. Journal of Geophysical Research-Solid Earth 118, 3285-3296.

Hunkins K.L., Mathieu G., Teeters S.R. \& Gill A. 1970. The floor of the Arctic Ocean in photographs. Arctic 23, 175-189.

Jakobsson M., Mayer L.A., Coakley B., Dowdeswell J.A., Forbes S., Fridman B., Hodnesdal H., Noormets R., 
Pedersen R., Rebesco M., Schenke H.-W., Zarayskaya Y., Accettella D., Armstrong A., Anderson R.M., Bienhoff P., Camerlenghi A., Church I., Edwards M., Gardner J. V., Hall J.K., Hell B., Hestvik O.B., Kristoffersen Y., Marcussen C., Mohammad R., Mosher D., Nghiem S. V., Pedrosa M.T., Travaglini P.G. \& Weatherall P. 2012. The International Bathymetric Chart of the Arctic Ocean (IBCAO) version 3.0. Geophysical Research Letters 39, L12609. doi:10.1029/2012GL052219

Jokat W. 2003. Seismic investigations along the western sector of Alpha Ridge, central Arctic Ocean. Geophysical Journal International 152, 185-201.

Kaban'kov V.Y., Andreeva I.A., Ivanov V.N. \& Petrova V.I. 2004. The geotectonic nature of the central Arctic morphostructures and geological implications of bottom sediments for its interpretation. Geotectonics 38, 430-442.

Kaban'kov V.Y., Andreeva I.A., Krupskaya V.V., Kaminskii D.V. \& Razuvaeva E.I. 2008. New data on the composition and origin of bottom sediments in the southern Mendeleev Rise (Arctic Ocean). Doklady Earth Sciences 419, 403-405.

Kristoffersen Y., Coakley B., Jokat W., Edwards M., Brekke H. \& Gjengedal J. 2004. Seabed erosion on the Lomonosov Ridge, central Arctic Ocean: a tale of deep draft icebergs in the Eurasia Basin and the influence of atlantic water inflow on iceberg motion? Paleoceanography 19, PA3006. doi:10.1029/2003PA000985

Krylov A.A., Stein R. \& Ermakova L.A. 2014. Clay minerals as indicators of late Quaternary sedimentation constraints in the Mendeleev Rise, Amerasian Basin, Arctic Ocean. Lithology and Mineral Resources 49, 103-116.

Morozov A.F., Petrov O.V., Šokalsky S.P., Kašubin S.N., Kremenecky A.A., Škatov M.J., Kaminsky V.D., Gusev E. A., Grikurov G.E., Rekant P.V., Ševčenko S.S., Sergeev S. A. \& Šatov V.V. 2013. Novye geologičeskie dannye, obosnovyvayuščie kontinental'nuju prirodu oblasti central'no-Arktičeskih podnjatij. (New geological data confirming continental origin of the central Arctic rises.) Regionalnaja Geologija i Metallogenija 53, 34-55.

Mosher D.C. 2012. 2011 Canadian High Arctic seismic expedition: CCGS Louis S. St-Laurent expedition report. Geological Survey of Canada Open File 7053. Ottawa: Geological Survey of Canada.

Niessen F., Hong J.K., Hegewald A., Matthiessen J., Stein R., Kim H., Kim S., Jensen L., Jokat W., Nam S.-I. \& Kang S.
2013. Repeated Pleistocene glaciation of the East Siberian continental margin. Nature Geoscience 6, 842-846.

Phillips R.L. \& Grantz A. 2001. Regional variations in provenance and abundance of ice-rafted clasts in Arctic Ocean sediments: implications for the configuration of late Quaternary oceanic and atmospheric circulation in the Arctic. Marine Geology 172, 91-115.

Polyak L., Edwards M.H., Coakley B.J. \& Jakobsson M. 2001. Ice shelves in the Pleistocene Arctic Ocean inferred from glaciogenic deep-sea bedforms. Nature 410, 453-457.

Rekant P.V., Mirolubova E.S., Andreeva I.A. \& Smirnova L. S. 2013. Sravnitel'nyj analiz mineral'nyh associacij donnyh otlozhenij prilaptevomorskogo segmenta hrebta Lomonosova i podnyatiya Mendeleeva kak odin iz kriteriev ocenki istochnikov oblomochnogo materiala. (Mineralogy of the bottom sediments from Lomonosov Ridge and Mendeleev Rise as a possible proxy to evaluation of the source rock.) Problemy Arktiki i Antarktiki 4, 79-95.

Shkatov M.Y. \& Ivanov G.I. 2013. First Russian borehole on the Arctic seafloor. Oceanology 53, 508-510.

Smirnov O.E. 2013. Riftogennye struktury zapadnogo sektora Amerazijskogo subbassejna po dannym kompleksnyh geofizicheskih issledovanij. (Riftogenic structures in the west sector of Amerasia Basin based on complex geophysical data.) Zapiski Gornogo Instituta 200, 86-91.

Stein R., Fahl K., Schreck M., Knorr G., Niessen F., Forwick M., Gebhardt C., Jensen L., Kaminski M., Kopf A., Matthiessen J., Jokat W. \& Lohmann G. 2016. Evidence for ice-free summers in the late Miocene central Arctic Ocean. Nature Communications 7, article no. 11148, doi: 10.1038/ncomms 11148

Stein R., Matthiessen J., Niessen F., Krylov A., Nam S. \& Bazhenova E. 2010. Towards a better (litho-) stratigraphy and reconstruction of Quaternary paleoenvironment in the Amerasian Basin (Arctic Ocean). Polarforschung 79, 97-121.

Vernikovsky V.A., Morozov A.F., Petrov O.V., Travin A.V., Kashubin S.N., Shokalsky S.P., Shevchenko S.S. \& Petrov E.O. 2014. New data for the age of dolerites and basalts from Mendeleev Rise: problem of continental crust of Arctic Ocean. Doklady Earth Sceinces 454, 431-435. 